\title{
An unanticipated successful career and some lessons learned
}

David C. Berliner

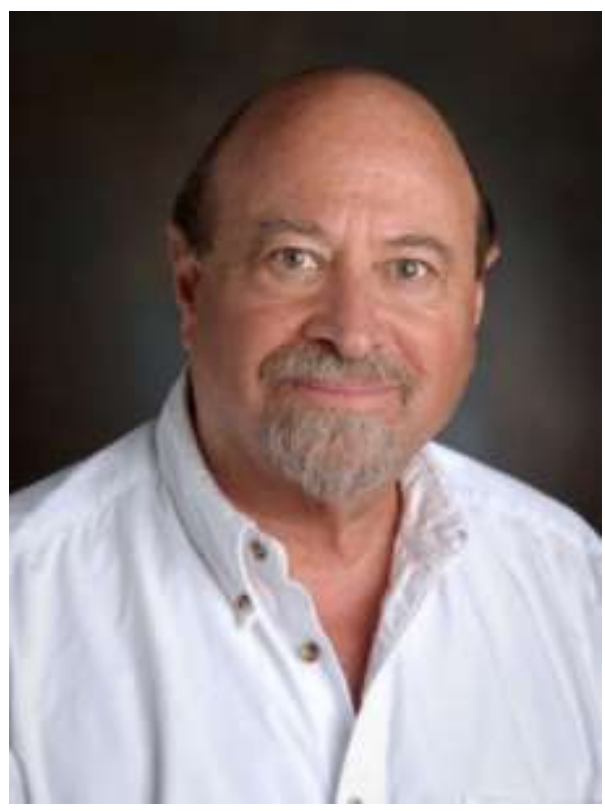

I was born at the end of the Great

Depression, 1938. I write this autobiographical essay 78 years later. By most criteria I am a successful scholar, a condition I continue to find amazing.

My academic work eventually pushed me toward attempts at understanding the relationship between poverty and schooling. That work led me to believe that you are, indeed, a very lucky person if you get three gifts when you are born: social, intellectual, and fiscal capital. Social capital is derived from your family's connections. These are the relationships with the folks who can nurture you —aunts and uncles, friends of your parents,

\footnotetext{
${ }^{1}$ Many of my academic accomplishments are documented elsewhere: my ASU faculty page, http://berliner.faculty.asu.edu/wordpress/; Wikipedia,
}

neighbors, role models from your place of worship, teachers who care about you.

These are the people who teach you how to be a decent person, to live a decent and productive life in the world we inherit. These people are the ones who whack you in the head when you do something stupid, call your mother if they see you playing with the "wrong" kids, or believe that you have been acting stupidly in the neighborhood. But they also buy you ice cream or give you a dollar bill when you make them happy or proud. I had all that. My parents were well integrated into their larger families on both sides, and they had a huge set of friends who often visited our apartment. Many of these people I called aunt or uncle, despite their being no blood relationship.

My only sibling was a brother who was seven years older. We were friendly, but I was not close to him as I grew up because of the age difference and our different interests. Now, in our later years, we live near each other and have become much closer, both remembering fondly and with gratitude, the lives our parents made for us. Our neighborhood in the Bronx, New York City, supplied each of us with social capital. Our neighborhood was closer to being a small town than Midwesterners could ever imagine! Lots of folks knew lots of other folks, and they often shopped at the same

http://en.wikipedia.org/wiki/David_Berliner; an interview in Roeper Review, 34(2), 77-80; and an Inside the Academy video, http://insidetheacademy.asu.edu/david-berliner

Berliner, D. C. (2016, May 11). An unanticipated successful career and some lessons learned. In S. Tobias, J. D. Fletcher, \& D. Berliner (Series Eds.), Acquired Wisdom Series. Education Review, 23. http://dx.doi.org/10.14507/er.v23.2078 
small shoemaker's shop, green grocer, and butcher. And they used the same barber and beauty shops. These people all knew my family.

I grew up quite secure in a few square blocks of what I learned later was a gigantic city that intimidated people from small towns. Urban life is just different. As a youngster, like many kids, I played a game called ring-a-levio, a "tag" like game invented in New York City but played in rural and suburban areas within a highly restricted geographical area. But in my neighborhood we played it on the NY subways, over three different train stations. I had no clue until later that urban life was so different from what many other Americans experienced.

Intellectual capital is a second gift that parents can give their children, and my parents gave that to me as well. My mother had graduated high school and my father had gone through $10^{\text {th }}$ grade. He toiled for more than 30 years as a low paid clerk for a drug store chain. Ultimately, through his efforts and that of hundreds of others, it became a union job. His work never paid well, but through the union he eventually had a 5-day and 40-hour work week, two weeks off with pay, and even, at retirement, a small pension.

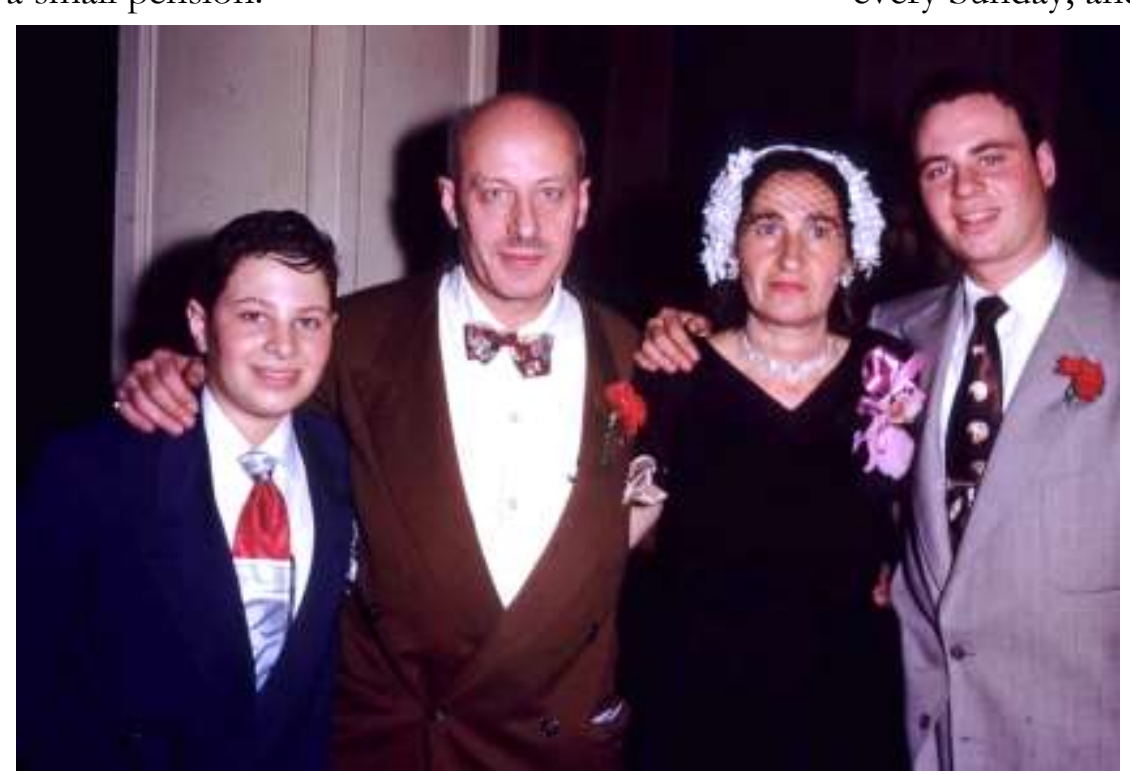

My father was a very moral man and I inherited many of his views on labor. Corporations, with a few wonderful exceptions, often have no conscience. They stand by while their employees are maimed or killed, and have done so with impunity (e.g., coal companies, the NFL). They will cheat their customers (Volkswagen, and too many banks to even mention); and they will hold back evidence of injuring employees or customers (GM, tobacco companies, and almost all of the chemical industry, along with big agriculture). I learned that corporations do these things without regret, often subverting government oversight, and breaking unions whenever they can.

My dad read two newspapers a day-one on the subway to work, and the other on the subway returning home. Political and social issues didn't dominate family life, but they were discussed. My father was a very gentle, quiet, caring man with many friends. His station in life made him understand the importance of belonging to a union and being a part of the Democratic Party machine.

My mother was a housewife until I was about 12 years old, and then entered the labor force so the family could have a bit more income. We got the New York Times every Sunday, and by Tuesday or so my mother had finished the crossword puzzle. She had a great vocabulary and was very quick mentally, probably with a very high IQ, had she ever been tested. She was a caring and protective mother though a bit overbearing for a young David. In more recent times, she would have been employed in some capacity other than as an unpaid housewife.

My parents were a long way from being intellectuals, but they did take me to shows and museums, talked enough about politics and world affairs to
David (age 13) at Bar Mitzvah, with father (Emanuel, Manny) mother (Nettie) and brother Steve. 
make me aware of more than sports and my friends, and encouraged my reading and my questions. So I inherited some intellectual capital, as well.

The third gift a lucky child can get is fiscal capital. My parents, however, were very working class. We lived in a homogenous working class neighborhood of tenements, a world that seemed safe and protective. I did not have a clue we were poor until my adolescence. They protected me from that.

I think that it is very difficult to grow up to be a bad or unsuccessful person if, at birth, you are blessed with all three gifts: social, intellectual and fiscal capital. It is also hard to grow up to be an unsuccessful adult if you have two of those gifts, as I had. A good deal of my professional life has been directed toward understanding how schooling can help those born with none of these three gifts. Imagine the child of a single mother who may not have finished high school. She is likely to provide her child little in the way of social, intellectual, or fiscal capital. No gifts! Imagine an immigrant family, speaking another language, arriving in this country with a low level of education, raising children in neighborhoods that are not safe. Social, intellectual, and fiscal capital may all be missing. Again, no gifts! Success in school is not easy for children who do not inherit these particular gifts. Schooling is much easier for those with all three of these gifts. I had two.

But the lack of fiscal capital was not a problem for me. Its absence meant only that I started work at an early age and learned lessons from those experiences that were also helpful in life. I started working at 12 years old delivering prescriptions after school, for tips. In high school, after school, I delivered fur coats during the autumn all over Manhattan. I also picked them up in the spring, returning them to the ice houses in which they resided during summers. My love for New York City grew as I explored the city during deliveries and pickups. New York to me was a magical city that left me with a love for urban life.
At that age I remember frequently passing through Grand Central Station because of my deliveries and pickups. I carefully watched, and envied, the wealthy men in their grey flannel suits; and on Wednesdays, I eyed the well- dressed woman from the suburbs with their white gloves, commuting into the city for the Broadway matinees. I wanted to be like them. So I decided that I would go into advertising so I could wear those suits, marry those kinds of women, and make "big money."

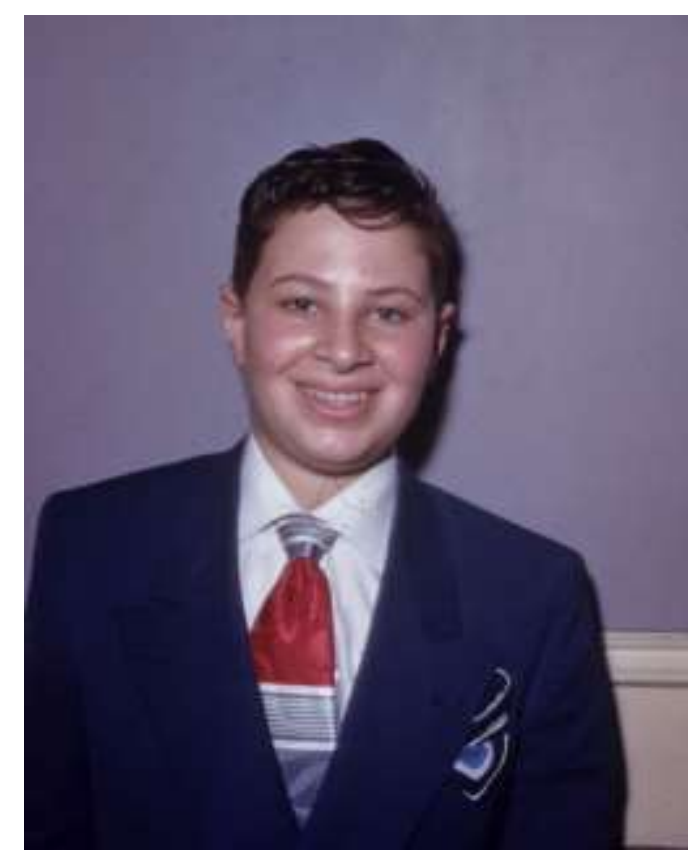

David at Bar Mitzvah

I was, however, a mediocre high school student at De Witt Clinton High School, in the north Bronx. It was a high school with well-over 2,000 boys and no girls! It was, therefore, more like an animal house than you can imagine. Of course, anyone who wanted a good education there could get one. But others of us only wanted to mark time until we got through adolescence. I wanted to play basketball, talk sports, tell tales that weren't true about my experiences with girls, and just "hang out" with my friends.

My elementary school had given me a healthy self-image, despite the fact that more than once they called my mother in to inform her I was "obstreperous" or that I 
“wasn't trying." But I was extremely well read, and that alone can get teachers to like you, and they often would cut me some slack. I got through grades K-9 easily, but from about the fourth grade on, I simply didn't care about school. This lack of caring was evident in high school as my best friend and I graduated exactly where we wanted to be-in the middle, as anonymous in a big school as we could be. In June of 1955, out of about 800 graduates, we graduated in ranks 399 and 400, completely ordinary, but still with "Regents' Degrees," which in New York means academic degrees.

I wasn't sure I wanted to go to college. I almost went into military service, but finally chose more schooling. My fantasies of grey flannel suited men and white gloved woman led me to the well regarded Bernard Baruch School of Business and Public Administration, part of the City Colleges of New York (CCNY, then, and independent college in the CUNY system now). The Baruch school was about a 20 -story office building in downtown Manhattan. Our "campus life" took place on one floor of the building, which made it very "un-ivy." I found the business courses remarkably boring and barely survived my first year, cutting classes, dropping courses, and getting Cs and Ds in others. Two exceptions were my introductory course in psychology, which I loved, and a U.S. history course that intrigued me and won me my first college "A."

At the same time that I was mostly screwing up, my best friend was equally bored in a different branch of CCNY where he was studying economics. He too was gearing up for a career in business. So at age 18, as bored, aspiring, and enterprising young businessmen, with small loans from our fathers, we bought a business. The business was only open during summers, and we bought it in the summer of 1956. It was a bar and grill. It was part of a hotel in Woodbridge, New York, a resort town about 100 miles north of New York City, in an area known as the Borscht Belt. At that time, at age 18, you could drink alcohol in New York State, but few 18-year-olds bought bars. That was one of five experiences that changed the direction of my professional life.

Life Changing Experience 1. My summer as an 18-year-old bartender brought me in touch with many older people who told me their life stories and troubles. I listened to tales of troubled marriages and work situations, I observed people making fools of themselves, and I heard fascinating tales about overcoming obstacles and achieving success and happiness. I met people whom I admired, people I felt sorry for, and people I didn't detest until after I served them two drinks. That summer I decided to switch from business, which was both boring and too easy (we made a good deal of money!), to psychology. The tales these people told fascinated me.

I now wanted to do clinical psychology and went back to school and started getting “As." Suddenly I liked my college courses. My Business Math class, in which I first got an $\mathrm{F}$ and then repeated and got a $\mathrm{D}$, was replaced with a general studies course in calculus in which I got an A.

Clearly motivation to learn, not academic ability, is among the most important of the variables teachers must understand and stimulate. I was on my way. I had a field I was interested in and switched from Business to Liberal Arts, from the Baruch School to CCNY uptown.

Life Changing Experience 2. A year later, as my college credits accumulated and my grades improved to A's and B's, I managed to prove to the world I was still quite a stupid young man. At age 20 I married and soon had my first child, the wonderful, smart, competent, and successful BethAnn Berliner, a senior researcher at WestEd, an educational research organization with headquarters in San Francisco. Now I was a husband and father, an aspiring clinical psychologist, and quite poor and reliant on emotional and fiscal support from working class parents and inlaws. To escape what we saw as our dependency, and with a desire to be treated 
as adults (though we really were not), my wife and I decided to move to California. I had fallen in love with California when I visited my brother there a few years earlier. Through a friend of my brother I was able to get a job as a printer on the swing shift at Douglas aircraft (now McDonnel-Douglas), working from about 4 p.m. in the afternoon to about midnight, five or six nights a week. This allowed me to go to UCLA, though I couldn't take more than nine units a semester because of family obligations and a full work schedule.

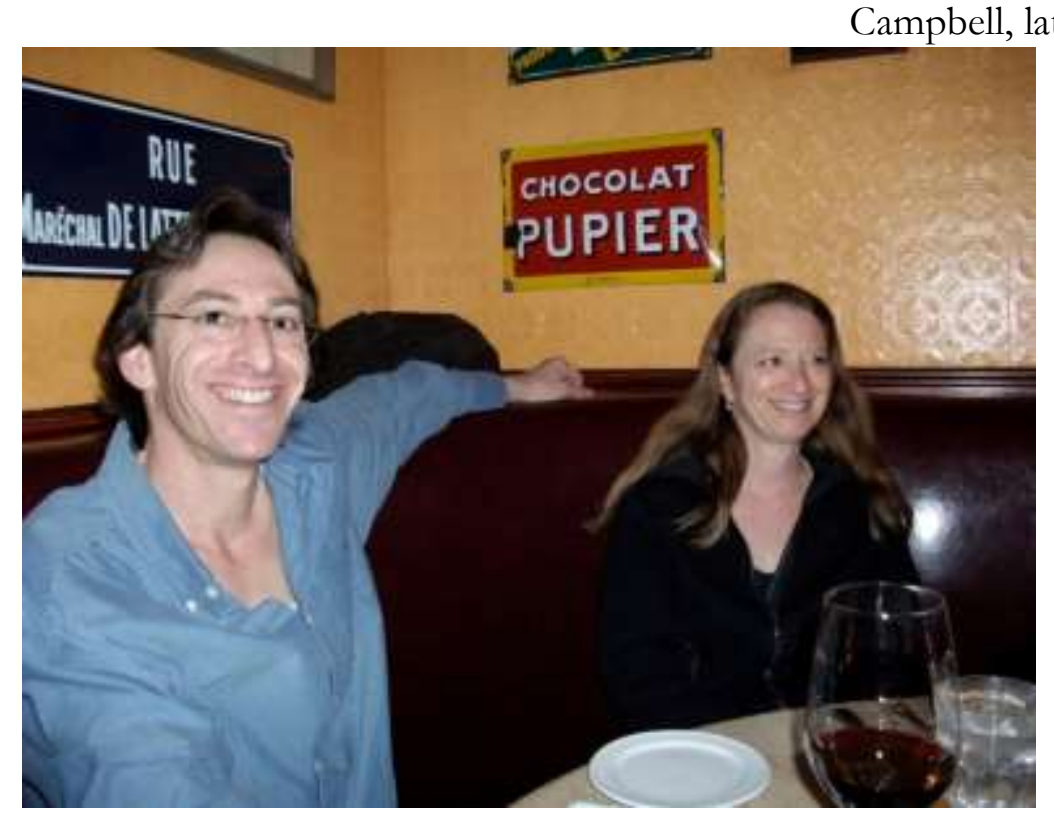

David's children, BethAnn and Brett Berliner

As I entered my last few semesters I was triple majored in sociology, anthropology, and psychology because all the social sciences were attractive to me. Still, I chose finally to get my bachelor's degree in psychology because it seemed the most likely of the three fields to help me get a job, and I still had a sense that clinical psychology was what I wanted to study.

However, because UCLA had no undergraduate major in clinical psych, they educated me fully in "scientific psychology," the experimental and quantitative parts of the field. Years later I realized that the broad social science background in which I was steeped was very helpful. For one, it led me to embrace qualitative methods in education research long before some of my more rigid colleagues in educational psychology did so. I also realized, just a year later, that UCLA had brain washed me, as I describe, below.

Among the instructors who impressed me at UCLA was a young Richard (Dick) Atkinson, soon to become one of the most distinguished psychologists, social scientists, and academic

administrators in the country. And I loved a course in social psychology from a summeronly visiting professor to UCLA. He too impressed me deeply. That was Donald Campbell, later also to become one of the most distinguished philosophers and methodologists in the social sciences. My son was born around this time, the wonderful, smart, competent, and successful Brett Alan Berliner, now Associate Professor of History at Morgan State University in Baltimore. But because I had to work to support my wife and two children, I could only continue my clinical training part time, and chose Los Angeles State College (LASC, but now, California State University, Los Angeles) for my master's degree. In my first semester there I secured an internship and helped counsel a couple as a way to develop my clinical skills. Simultaneously, I took a course on the psychoanalytic theory of the neurosis. I was finally doing what I wanted to do.

But then a problem arose. When counseling the couple I cried with them at every session, felt I had nothing to offer, and was drained by the 50 minutes of heartbreaking emotional labor. And in the middle of the clinical course I asked my professor if it was possible that the therapists we were reading about were crazier than the patients they were treating. I thought that the therapists in these case studies were offering bizarre and unscientific rationales for the behavior that 
they observed. UCLA had, indeed, brainwashed me.

The professor, a true believer, literally threw me out of class! I discovered that I was an experimental psychologist, not a clinical psychologist at all. I liked the science of psychology, particularly learning theory, experimental design, and statistical inference. I did not like what I took to be the "loose thinking" and the inevitable emotional drain I believed characterized clinical psychology.

Fortunately, that semester, I had another course that taught experimental design, with Herbert Moskowitz, a researcher at the medical school at UCLA. I liked and admired him, enjoyed the course he taught, and asked him to help me become an experimental psychologist. $\mathrm{He}$ was a wonderful scientist as well as a kind man, who took me into his laboratory at UCLA where I studied the effects of alcohol on rats. He was well known in this field, and eventually the blood level alcohol rates used by police and courts to assess drunk driving were based on his research.

What fun I had. I served a wonderful apprenticeship among real scientists. And I even had a white lab coat with which to wander the UCLA brain research center as if I were a genuine scientist or physician, instead of a lowly research assistant. I learned a lot about experimental psychology, randomized trials, and the problems inherent in trying to attain objectivity in research, even with rats, some of which were a lot more loveable than others! That work led me to be quite skeptical of all scientific findings that have

\footnotetext{
2 Steinberg, A., \& Berliner, D. C. (1963, October). Human error: Identification of causes. Engineering Paper No. 1747. Paper presented at the meetings of the Human Factors Society, Palo Alto, CA. Santa Monica, CA: Douglas Aircraft Co., Missile and Space Systems Division. ${ }^{3}$ These reports had such titles as: Berliner, D. C., \& Fazio, J. L. (1963). Qualitative and quantitative personnel requirements for infrared detecting set AN/AAS-18 (Unclassified title). Los Angeles:
}

not been replicated by a different team of researchers.

In January, 1963, my master's in psychology was awarded from LASC. I soon found that Douglas Aircraft would hire me back, not as a printer, but as a human factors engineer. Those were experimental psychologists interested in the man-machine interface, its problems and affordances. I finally had a real professional job, and it even paid well! I worked on the Saturn 5 rocket that eventually got the US to the moon. I authored my first professional paper for the company and I was allowed to present it at my first conference, where I learned something about the norms of the research community. ${ }^{2}$

My work for Douglas Aircraft was appreciated by the team leader of a subcontractor on our project, an employee of the American Institutes for Research (AIR). They made me an even better offer, and I joined AIR. They sent me off to Dallas, Texas, where I worked on human factors projects for Texas Instrument Company and published a series of short technical reports that were all classified ${ }^{3}$. AIR ultimately shipped me to their (then) newly opened Palo Alto office where I continued to work on human factors projects, and got my first taste of education research, in a project designed to improve Naval training systems through the use of simulators. I had a kind and knowledgeable boss, David Angell, and with him and another colleague, published a paper that was a unique cognitive perspective on simulation training. ${ }^{4}$ This 1964 paper, one of my first, went on to become a classic in the energy transmission field, a standard

American Institutes for Research. AIR-D484/63-TR(1). CONFIDENTIAL. (Texas Instruments Apparatus Division Report No. C12-67801-12). If I revealed their contents to you we might both be jailed!

${ }^{4}$ Berliner, D. C., Angell, D., \& Shearer, J. W. (1964, August). Behaviors, measures, and instruments for performance evaluation in simulated environments. Proceedings, symposium on the Quantification of Human Performance. Albuquerque, NM. 
reference for those who do task analysis, and even now is still cited frequently in books and articles on human factors.

At the time I didn't know how well cited that paper was to become, but I became aware that I was being noticed. I began to feel I had something to offer my field of psychology. It was about then that I realized that I would never lead my own projects in organizations like AIR if I didn't have a doctorate. So, I applied for doctoral training in experimental psychology at the two closest universities, UC Berkeley and Stanford. AIR provided me good references, I was already "published" a little, and at AIR I had met with such luminaries in psychology, education, and the world of training, as Robert Glaser, Robert Gagne, and John Flanagan. Therefore, I thought, I was a good candidate for doctoral studies. Berkeley accepted me, but Stanford did not. However, my third life changing experience occurred at this time.

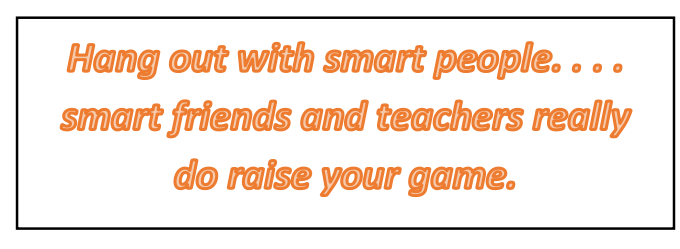

admitted to Stanford's School of Education without ever applying to it.

I quickly looked up what the heck educational psychology was, interviewed with Coladarci, walked the beautiful campus, and thought, how can I go wrong! In the four years at Stanford my life changed. It was, and probably still is, a life changing institution. It did for me what the university experience is supposed to do: it changed me. I have written about this, an homage to powerful environments for learning. ${ }^{5}$

Of course it is the people within those environments that primarily shape us. At the start of my first semester at Stanford I was hired as a research assistant for the "new math" research team. Included in that group were education scholars such as its director, Ed Begle, and two research assistants who went on to leadership roles in mathematics education: Jeremy Kilpatrick and Jimmie Wilson. I became very close friends with my boss, the creative and unusual scholar Leonard

Cahen. While I worked for him at Stanford, eventually he worked for me at the Far West Laboratory. For a long time he was my closest friend, and like many others, died too young. At Stanford I also took course work with Albert Bandura, Ernest (Jack) Hilgard, Quinn McNemar and studied with and was research assistant to Lee J. Cronbach, one of the two most influential people in my professional career. Many of these scholars were APA presidents.

At Stanford I met and studied with the second person who most influenced my professional career: N. L. Gage. He was my mentor, colleague, and avuncular dear friend. I also studied with Dick Atkinson (mentioned above) and his co-developer of computer programs for learning, Patrick Suppes. Their versions of computer-assisted instruction were a marvel in those "ancient" times. Both Suppes and Gage served as

a Teacher Eternal: Scholars Describe the Teacher Who Made a Difference (pp. 195-203). Charlotte, NC: Information Age Publishers.
${ }^{5}$ Berliner, D. C. (2008). A Culture and its
Representatives. In F. Pajares and T. Urdan
(Eds.), Adolescence and education, Volume 6. Making 
presidents of the American Educational Research Association (AERA), as did Elliot Eisner, whom I knew at Stanford and was influenced by, but did not study with.

I met and was influenced by, but did not study with, Ralph Tyler. And I worked with an influential, energetic, highly creative educator, and the father of microteaching, Dwight Allen. Dwight was very kind to me. I worked on some microteaching studies with Dwight and my educational psychology advisor, Fredrick McDonald, and I published on this topic. ${ }^{6}$ That work developed in me a commitment to the study of teaching, a theme still prevalent in all my work. My enduring friendship with Barak Rosenshine, a leading scholar of research on teaching started at that time. For almost 50 years now, through emails sent a few times each week, we have argued about research on teaching. The superb psychologist Richard Snow, who passed away too young, was another source of influence on me, and he too became a dear and influential friend.

I also studied with the father of contemporary educational anthropology, George Spindler, and the learning theorists William Estes and Gordon Bower. The latter was advisor to at least two others who are writing for this series, Alan Lesgold and Robert Sternberg (whom I taught educational psychology, using a trial edition of Gage and Berliner ').

I am amazed that with such ordinary beginnings I ended up with such a superb pedigree. I was educated by many of the greatest psychologists and educators of their times. It came about by chance, but there is nothing quite like studying with, and getting to know, productive senior members of your profession. They all had earned their reputations and leadership positions for a reason. And that reason is often obvious after only a meeting or two, or a class or

\footnotetext{
${ }^{6}$ Berliner, D. C. (1969). Microteaching and the technical skills approach to teacher training. Technical Report No. 8. Stanford, CA: Stanford University, Center for Research and Development in Teaching, School of Education.
}

two. I will comment more on this in the last section, on lessons learned.

The Post PhD Years. I left Stanford in the summer of 1968 for the University of Massachusetts at Amherst, having been wooed by their new dean, Dwight Allen, whom I had worked for at Stanford. The free speech movement had started earlier, up the road at Berkeley. The Democratic national convention in Chicago was the scene of a police riot as I moved my family across the country. Campuses everywhere were in turmoil; Viet Nam war protests and youthful rebellion in music and in sexual behavior were common in these times.

The newly formed College of Education at UMass reflected the times. It was a very unusual place, tolerating many unique students who advocated unusual positions on seemingly any topic that could be named. It was a most amazing time in campus life and in American history! Like so many of my generation, I remember the campus protests of those years, marching with my family to end the Viet Nam war, and I can never forget the Kent State shootings of unarmed protesting students. It was a serious (though sometimes joyous) time, as students and faculty across the nation took down a sitting president (Lyndon Johnson) and would not quiet down.

University life was noticeably changing. Although their numbers were not yet large, it was quite evident that we had many more black and Hispanic students in our program than previously. And women were a growing proportion of our doctoral students and were becoming leaders in campus politics among the students and in academic units throughout the campus. Evidence of a changing American culture was everywhere; but with a wife, and two children, and hardly any income, I was only an observer of this phenomenon until I

\footnotetext{
${ }^{7}$ Gage, N. L., \& Berliner, D. C. (1975). Educational psychology. Chicago: Rand McNally.
} This was the first of six editions. 
received my degree. My first forays into political activism began at UMass, during my first academic position, and during those tumultuous times.

Upon arrival at UMass, I was promptly named head of the department of educational psychology and research methods, approximately 15 days after I had obtained my own doctorate! Although knowing nothing about administration I worked hard to establish our new center. And UMass, in the years since, had quite a few distinguished educational researchers associated with it, one of whom, Ron Hambleton, I hired during my brief time there. I published a few things while there, including the only statistical computer program I ever wrote. ${ }^{8}$ I needed that program to analyze a unique set of data from my dissertation which was concerned with Aptitude-Treatment-Interaction, ATI, a style of research intellectually associated with Cronbach and Snow. I admired this approach to research, as did Sigmund Tobias, among others. He is one of the other editors of this series. We have been friends and colleagues for many years. ATI aficionados met as a SIG, a Special Interest Group concerned with ATIs at the meetings of AERA, and at Division 15 meetings, the Educational Psychology Division of the American Psychological Association (APA). I built wonderful friendships with others interested in ATIs, and somehow I ended up president of the SIG, and that started my becoming more active in AERA.

New England, however, did not agree with my family, who longed to return to California. And I was not happy there either. Although brought up in New York City, my first and only arrest was in Amherst. We were leaders of a rent strike against a mean and powerful landlord. After all, it was the 60s! But he really was mean

\footnotetext{
${ }^{8}$ Dowaliby, F. J., \& Berliner, D. C. (1971). ANALATI: A computer program for the application of the Johnson Neyman technique in the case of one predictor and one criterion variable. Technical Report No. 15. Amherst,
}

and powerful and that resulted in our getting arrested and evicted. Bucolic New England, "quaint small town life," was actually quite trying. And so, California beckoned once again.

As I inquired about job possibilities I was offered a chance to work for a small research organization in Berkeley, called the Far West Laboratory for Educational Research and Development (FWL, now called WestEd and headquartered in San Francisco. It now employs about 500 people). A few years earlier, FWL had been established by the federal government, along with about 10 other laboratories, to help transform education research into the kinds of practical educational products and programs that could be used by teachers and administrators.

In the beginning, I worked on the design of "protocol" materials, video and film instantiations of important teaching concepts. Instead of just reading about the concepts that made up a teacher education program, such as "corrective feedback," or "gender bias in questioning," or "using student ideas," or "questioning at higher levels of the Bloom taxonomy," we videotaped or filmed teachers practicing these concepts in natural classrooms. We built training materials out of these "captured" moments, these instantiations of the concepts we tried to illustrate. We had hoped that teacher education institutions would use them. Great idea. Good work was done. But it never caught on, and protocol material is now lost to history.

The project was jointly administered with Stanford and so I had two supervisors. One was N. L. Gage, "Nate," of Stanford. The other and more immediate supervisor was the talented, helpful, and humorous psychologist Walter Borg, whose work in training research and on applying

MA: University of Massachusetts, School of Education, Center for Educational Research. ${ }^{9}$ Cronbach, L. J., \& Snow, R. (1977). Aptitudes and Instructional Methods: A Handbook. for Research on Interactions. New York: Irvington. 
psychology and measurement to education is still influencing our field. ${ }^{10}$

By a quirk of fate, one of my research assistants on that project was a graduate student in linguistics at Stanford, who didn't know much about education at all. But our work was tied to linguistics in that every filmed protocol was an instantiation of a complex educational or psychological linguistic concept, and that was the natural domain of linguists, not educational psychologists. So I asked that research assistant, James Gee, to help me write about these issues. He did, and I was stunned by the quality of his contribution. Jim became the first author of a book length manuscript that came out of that project. ${ }^{11}$ Today he is internationally recognized as a scholar in linguistics, and more recently recognized for his work in learning games. He is now, as well, my colleague at Arizona State University.

The head of this project at the national level was also a philosopher, curriculum theorist, and teacher educator of great repute: B. Othanel Smith. He was among the best of his generation, a man of great wisdom and charm whom I grew quite close to as he did to me. I continued my work at FWL for another few years, publishing regularly and also eventually being named director of research there. While in that role I won a large multi-year grant with the peculiar title "The Beginning Teacher Evaluation Project” (BTES) For a number of years we studied how teachers used classroom time, and we invented an unusual, and I think remarkable concept,

${ }^{10}$ See Gall, M. D. (1991). In Memoriam: Walter R. Borg. The Journal of Experimental Education, 59(2), 107-109. And Borg, W. Educational

Research: An Introduction. (2007). Boston, MA: Pearson/Allyn and Bacon. This book is now its eighth edition and kept up-to-date by Meredith and Joyce Gall, also connected with Far West Laboratory in its early days.

${ }^{11}$ Gee, J., \& Berliner, D. C. (1971). Protocols: A new dimension in teacher education. Final report for Contract No. OEC-0-71-0266. Washington, D. C.: U.S. Office of Education, Department of Health, Education, and Welfare.
ALT, Academic Learning Time. ${ }^{12}$ My work on this project resulted in more publications and presentations, and greater national visibility in both AERA and APA. My international work also expanded at this time.

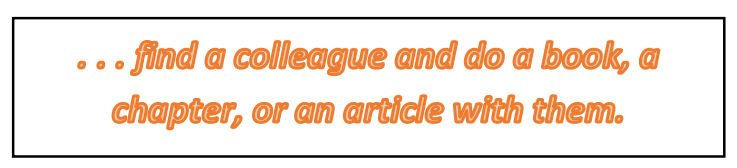

Life changing experience number

4. I had been offered the job at FWL through N. L. Gage, who jointly administered the protocol project through the Stanford Center for Research and Development in Teaching, where I had been a research assistant during my doctoral program. But along with the job, Nate offered me the chance of a lifetime: to coauthor with him a text on educational psychology. In 1963, just before I arrived at Stanford, the first Handbook of Research on Teaching was published. Nate had edited that volume, and it was an intellectually rigorous founding document for the field of research on teaching. The publisher offered him a contract to do an educational psychology text as a follow-up, but he made no headway on his own. Like me, he liked to write with others. Working alone for four years failed to produce very much.

Nate then asked his friend, Philip Jackson of the University of Chicago to join him in this endeavor. But Phil was working on his ground-breaking book Life in Classrooms (1968). That was a unique book in our field, more anthropological than psychological. That work soured Phil on

12 Berliner, D. C. (1990). What's all the fuss about instructional time? In M. Ben Peretz and R. Bromme (Eds.), The nature of time in schools (pp. 3-35). New York: Teachers College Press. See also Berliner, D. C., Filby, N. N., Marliave, R., Cahen, L. S., \& Dishaw, M. M. (1980). Teaching Behaviors, Academic Learning Time, and Student Achievement: An Overview. In C. Denham \& A. Lieberman (Eds.), Time To Learn (pp. 7-32). Washington, D.C.: National Institute of Education. And also Fisher, C. W., \& Berliner, D. C., (Eds.). (1985). Perspectives on Instructional Time. New York: Longman. 
what he saw as a traditional and irrelevant psychology of education. So he turned Nate down. Nate then turned to a relatively new faculty member whom we all regarded as superbly gifted, Richard Snow. Dick told Nate that he was really an industrial psychologist who wandered into education because of his work on ATI. He didn't feel that he knew the field well enough to do an educational psychology text.

Thank you Phil and Dick! My chance came next. Dick reminded Nate that I had recently graduated, been a top flight student, knew the field well, wanted to come back to California, and that I might be a good co-author. I had received a top grade and personal praise from Nate when I had taken his social psychology of education course, and I had worked in the R and D Center that he helped administer. So he knew me and soon invited me to head the new project Stanford and FWL were administering on protocols, and to also join him in writing the textbook. I then left New England, happy to have new opportunities.

Although working at FWL, I took almost every Friday and Saturday off from 1970 to 1975 to write with, chat with, laugh with and share life with Nate. In 1975, we published the first edition of Gage and Berliner's Educational Psychology, through Rand McNally publishing. The book was successful, subsequently bought by Houghton-Mifflin, and it eventually went through six editions. It sold well all over the world but was particularly a hit in Germany. Our book allowed Gage and me the chance to influence a whole generation of educational psychologists worldwide. Among the innovations we were most proud of was that for the first time in an educational psychology text there were explicit chapters

${ }^{13}$ Berliner, D. C. (2003). Toiling in Pasteur's Quadrant: The Contributions of N. L. Gage to Educational Psychology. In B. Zimmerman \& on the psychology of teaching, the field that Gage was acknowledged to be the father of, and the field in which I was developing my own career. Gage, as mentor was an extraordinary scholar, and he and his wife Maggie were beloved friends. ${ }^{13}$

As we wrote the book, I continued my work at FWL, and with a number of other researchers who conducted research on teaching, including Gage, we began informal meetings on that topic. Among the researchers I remember at the early meetings were Jere Brophy, Tom Good, Barak Rosenshine, Lee Shulman, and many of Nate's students, almost all of whom went on to their own distinguished careers. Those of us who were defining the research agendas for the field of research on teaching met for a number of years under the title "The Invisible College." This was a term coined by the sociologist of science Robert Merton to describe a group of scientists who meet because of their mutual interests in an emerging field, as research on teaching was. Life-long friends were made there. There was support by everyone for the work each of us was doing. At these meetings, and at

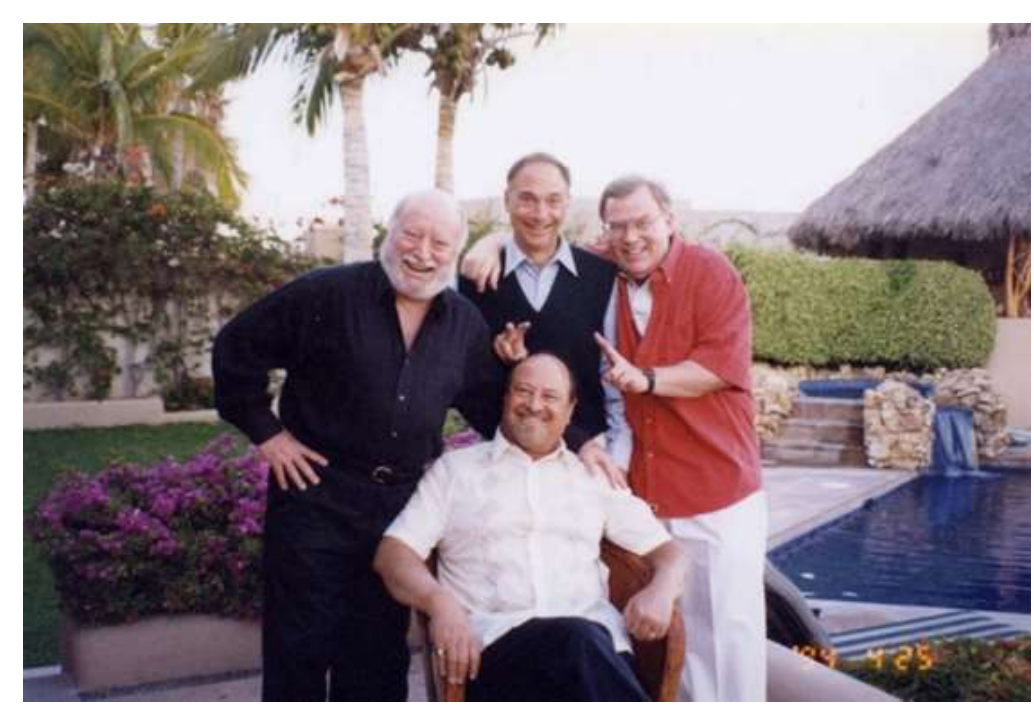

Lee Shulman, Rich Shavelson and Gary Fenstermacher, celebrating David's 65th birthday in Cabo
D. Schunk (Eds.), Educational psychology: A century of contributions (pp. 391-408). Mahwah, NJ: Lawrence Erlbaum. 
other professional meetings, I cemented three enduring friendships with those who shared an interest in the study of teaching: Gary Fenstermacher, Richard Shavelson, and Lee Shulman, all of whom achieved eminence in their careers. The four of us, and our spouses, still get together regularly, tell tall tales about the research we did and did not do, and drink better wine than when we were younger. But we no longer can drink as much!

Somewhere in this productive period of writing and research at FWL, my wife and I divorced and I received custody of my two children. It was a good time for the three of us for a number of years, with my daughter eventually going off to UC Santa Barbara, and my son finishing up high school, and eventually going to UC Berkeley. I was also eager to get back to academe at this time, and with a new wife, also an academic, we took positions at the University of Arizona. My second wife did not like Arizona and returned to her position in California, but I stayed on, serving as department head of educational psychology for many years.

Soon after arriving at $\mathrm{U}$ of $\mathrm{A}, \mathrm{I}$ became fascinated with the work on the psychology of "expertise." My work in classrooms, when heading the BTES project, had put me in contact with teachers whom I judged to be experts, remarkable instructors, who daily displayed their prowess. So, with funding from the Spencer Foundation, I started a research project to identify and study expert teachers. I spent the next decade or so studying that concept and publishing widely in that area. ${ }^{14}$

In 1981-1982 I went to Washington

DC to convene a conference for the National Institutes of Education (NIE). We wanted to see what we had accomplished

${ }_{14}$ Berliner, D. C. (1986). In pursuit of the expert pedagogue. Educational Researcher, 15(7), 5-13.

(This paper was also presented as the Presidential Address at the annual meeting of the American Educational Research Association, San Francisco, California, April, 1986.). See also Berliner, D. C. (1994). Expertise: The wonders since the first conference on research on teaching a decade earlier, held under the direction of Nate Gage. What had the funding and support for research on teaching wrought? My work there was supervised by Virginia Richardson, who may have brought me in because I was single and had no children at home, as well as for my scholarship and administrative abilities. As though fated, I soon met Ursula Casanova, a former teacher and school principal who worked at NIE. We have been partners and then husband and wife now for 35 years. Ursula subsequently earned her $\mathrm{PhD}$ in education and joined me as a faculty member at Arizona State University, where we have been since 1987 .

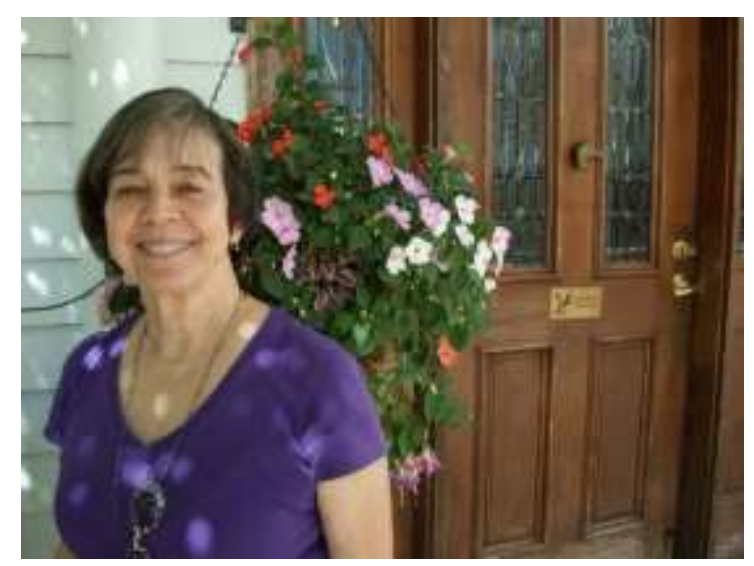

Ursula Casanova, David's wife

The Washington conference took place at the very start of the Reagan years. Everything we learned at this successful conference indicated that continued research on teaching could help public schools become better. ${ }^{15}$ It was a smashing success, and therefore, such research had to be stopped! It was clearly not the intention of that administration to have public education improve.

of exemplary performance. In John N. Mangieri \& Cathy Collins Block (Eds.), Creating powerful thinking in teachers and students (pp. 141-186). Fort Worth, TX: Holt, Rinehart and Winston.

${ }^{15}$ Much of the conference is described in a 1983 Special Issue on Research on Teaching, Elementary School Journal, 83(4), which I edited. 
Reagan asked his new Secretary of Education, Terrel Bell, to dismantle the Department of Education. NIE was almost shuttered. Attempts to denigrate the achievements of public education were systemic. These attacks on public education were organized and paid for by the freemarket, conservative, anti-public school advocates within the Reagan administration and in the Republican Party. This was made manifest in what may have been the most influential and dishonest report about education ever issued, $A$ Nation at Risk. The report directly led to another life changing moment in my life, described below.

Those years at the University of Arizona were highly productive, as were those shortly thereafter at Arizona State University. We moved to ASU because my wife had no opportunity to obtain an academic appointment at $\mathrm{U}$ of $\mathrm{A}$ and $\mathrm{ASU}$ welcomed us as a couple. Spousal and partner hires were a little trickier to negotiate in the mid-1980s, but Gladys Styles Johnson, the dean at ASU, used such appointments successfully to build a research faculty at ASU.

This was a time in which I increased professional service to AERA and to Division 15 of the American Psychological Association, APA. My publications and my service earned me the presidency of AERA in 1985, and in 1993 I was elected as President of Division 15 of APA, the Division of Educational Psychology. These honors made me very proud.

So these were busy years in scholarship to inform my field of interest, and in service to my profession. Almost all of my professional work was associated with my educational psychological research on instructional time, teacher education, expertise in teaching, evaluation of teachers, the nature of the field of educational psychology, and so forth. But then another life changing event occurred.

${ }^{16}$ Berliner, D. C. (1991, August). If they called, what would we say? Educational Psychology's answer to school reform. Paper presented at the

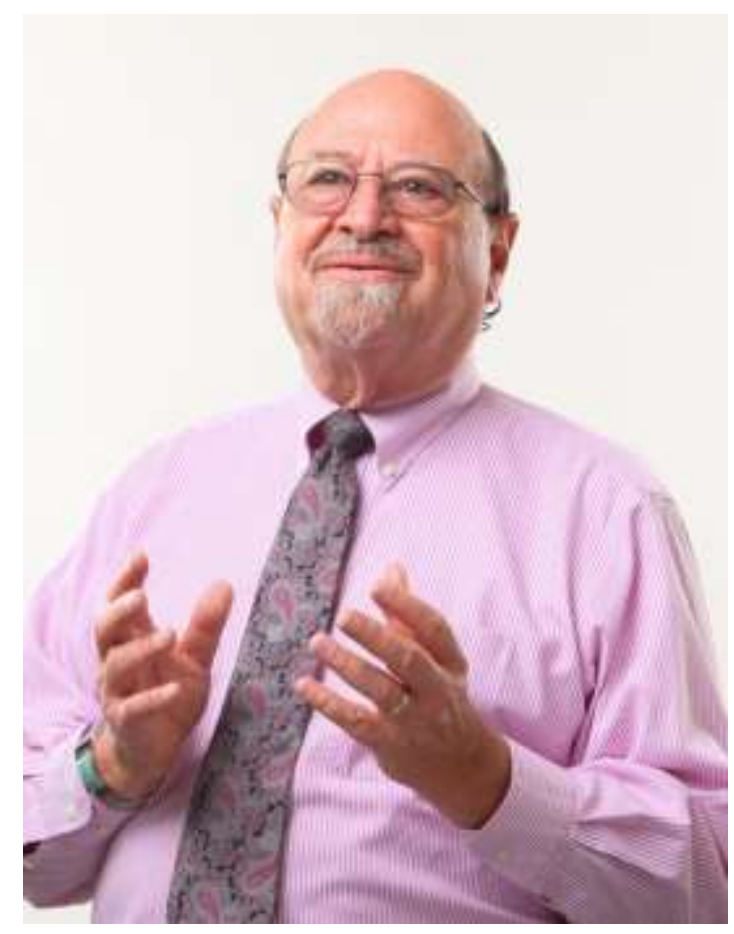

Life changing event 5 . At the meetings of the APA in August, 1991, I was chair of a panel on school reform. ${ }^{16}$ Every one of the panelists had criticized the schools, buying into the decade long attack launched with $A$ Nation at Risk, and promulgated even more by Reagan's second Secretary of Education, the bombastic, hypocritical moralist, William Bennett. I asked those on the panel to raise their hands if they had visited an American public school classroom in the last 90 days. I was the only panelist to raise my hand. I then excoriated them all for their lack of empiricism. I stated that American public education was remarkably good, teachers were remarkably able and kind, and that the nonsense they were spouting simply wasn't part of my experience while visiting dozens of classrooms over the previous few months.

In the audience was the talented, witty, and delightfully confrontational scholar Gerald Bracey. He rushed up to me to tell me that he had just written on that issue, and we soon were trading papers on how good the American schools really were,

meetings of the American Psychological Association, San Francisco, CA. 
and how deceitful many of its critics were. Also in the audience that day was my friend and mentor N. L. Gage who said to me "where's the data-you shouldn't talk about these things without data." He was right, of course, and I thought deeply about that.

Fate intervened again. A week later my friend Gary Fenstermacher, as president of the American Association of Colleges for Teacher Education, asked if I would give the keynote speech on expert teachers at their February meetings. I agreed, as long as I could change the topic to something like "How good are the American Schools?" He agreed and I had about six months to take Gage seriously and speak with, and from, supportive data.

I worked hard on that talk, making use of a remarkable report that Bracey and I obtained from the Sandia Corporation that thoroughly supported our position. The Reagan administration suppressed that report for years, but it was leaked to us by a brave research scientist who had risked losing his job by doing so. ${ }^{17}$

The night before I gave my talk I tried it out on my wife, Ursula. She said "tomorrow your career changes." She was right. I gave the talk to wild applause by a few hundred deans of education. Apparently I shot one of the first salvos in the fight against those who wanted to destroy our public schools with lies. Thousands of Xerox copies of my talk were reproduced and distributed. And, a little later, at the urging of my friend Gene Glass, founding editor of what soon would become the premiere on-line open access policy journal in the world, Educational Policy Analysis Archives, I turned the talk into a journal article. ${ }^{18}$ It set a record for downloads in its day, a time before computers had become indispensable among researchers. I had moved from a successful career as an educational psychologist interested in research on teaching, to being a policy

${ }^{17}$ Carson, C. C., Huelskamp, R. M., \& Woodall, T. D. (May, 1991). Perspectives on Education in America (3 ${ }^{\text {rd }}$ Draft). Sandia National Laboratories: Albuquerque, New Mexico. analyst. I immediately had to read a book on what policy analysis actually was, loaned to me by friend and colleague Mary Lee Smith! Soon after that, at dinner with Bruce J. Biddle, a brilliant social psychologist and sociologist who did ground breaking work in research on teaching, the topic of that paper came up. He insisted that I do a book on all the lying we both believed was going on about schools. I said I didn't have the skills to deal with many of the areas that needed to be covered in such a book, but we agreed that he did. So we joined forces. What a joy it was to work with this marvelous man whose sense of moral outrage was as strong as my own, and whose scholarship was far better. In near record time we jointly produced The Manufactured Crisis: Myth, Fraud, and the Attack on America's Public Schools, a best seller and winner of AERA's annual best book award, and named by a museum of

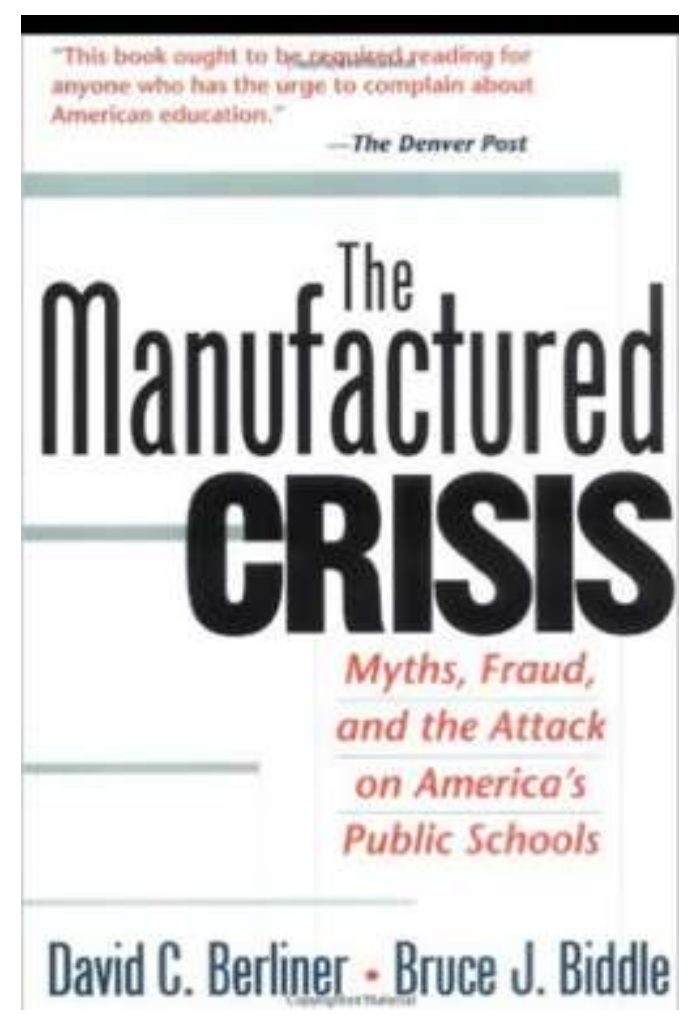

${ }^{18}$ Berliner, D. C. (1993). Educational reform in an era of disinformation. Educational Policy Analysis Archives, 1(2). http://dx.doi.org/10.14507/epaa.v1n2.1993 
education as one of the most influential books of the $20^{\text {th }}$ century. ${ }^{19}$

About this same time I was also working on issues concerned with educational psychology, the field of study I had found so rich and rewarding until I accidently became enmeshed in policy issues. I always enjoyed history as a student, raised two historians, and so I leapt at a chance to do a history of educational psychology for the American Psychological Association. I found it both enjoyable and fascinating to read or reread William James, John Dewey, E. L. Thorndike and others who laid the foundations for my chosen field of study. ${ }^{20}$

I also finished work I had started many years earlier with my friend Robert (Bob) Calfee. We both believed we had a significant project to accomplish for our chosen field of educational psychology. With the blessings of Division 15 of APA, presided over by the editor of this series, Sig Tobias, we set about planning, commissioning, and editing the first Handbook of Educational Psychology. ${ }^{21}$ We both viewed this attempt at defining and systematizing the field of educational psychology as a gift to our field. But in general, the focus of my work on classroom teachers, teacher education, and the field of educational psychology, shifted to issues concerning public schooling in America, and the nature of education and our democracy. These were bigger issues than I ever dreamed of addressing at the start of my career

\footnotetext{
${ }^{19}$ See Museum of Education, University of South Carolina, the section on Readers Guide to Education. Retrieved March 15, 2016, from http://www.ed.sc.edu/museum/Guide.html 20 Berliner, D. C. (1993). The science of psychology and the practice of schooling: The one hundred year journey of educational psychology from interest, to disdain, to respect for practice. In T. K. Fagan \& G. R. VandenBog (Eds.), Exploring applied psychology: Origins and critical analysis: Master lecturers, 1992. Washington, D. C.: American Psychological Association. See also Berliner, D. C. (2006). Educational
}

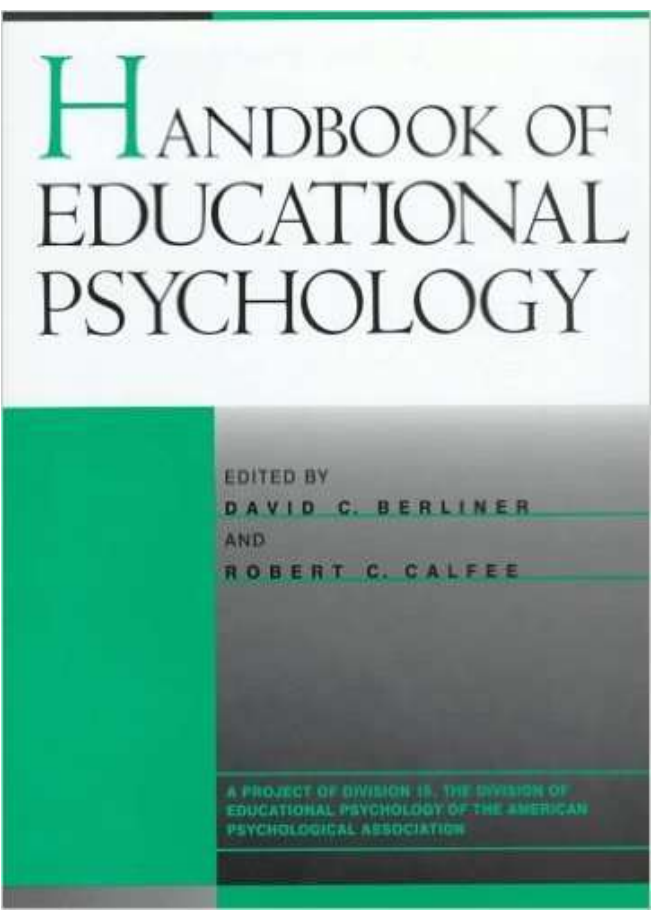

In the years since becoming enamored of and enmeshed in issues of education policy, from the 1995 publication of The Manufactured Crisis until today, in my late seventies, I have explored deeply several education policy issues. Particularly satisfying to me was finding that my work on teacher expertise was useful to the emerging National Board for Professional Teacher Standards (NBPTS). I helped design their initial testing programs and I have supported policies to expand the National Board. I was also able to do a small study demonstrating that, indeed, Nationally Board Certified teachers appeared to produce better student achievement than non-board certified teachers. ${ }^{22}$ As Dean of the College of Education at ASU (1997-

psychology: Searching for essence throughout a century of influence (pp. 3-27). In P. Alexander \& P. Winne (Eds.), Handbook of educational psychology (2nd ed.). Mahwah, NJ: Lawrence Erlbaum.

${ }^{21}$ Berliner, D. C., \& Calfee, R. C. (Eds.) (1996). The handbook of educational psychology. New York: Macmillan.

22 Vandevoort, L. G., Amrein-Beardsley, A. \& Berliner, D. C. (2004). National board certified teachers and their students' achievement. Education Policy Analysis Archives, 12(46). http://dx.doi.org/10.14507/epaa.v12n46.2004 
2001) I obtained funding for and began a training program for Nationally Board Certified Teachers. When I began this program we had one board certified teacher in the state of Arizona; today we have about 1,200 , and I am proud to have been a part of that history.

My deanship was unexpected. I was never a candidate for the job. Rather, after some leadership problems emerged, I was drafted by the university's provost. With two extraordinary associate deans, Gene Glass and Gail Hackett, we hired some very talented people, enhanced the college's reputation, increased its external funding, and had more fun than we ever believed we could. Besides the push to have ASU support National Board Certified Teachers, my deanship allowed me to bring a policy laboratory to ASU, located originally at the University of Wisconsin, Milwaukee, and run by Alex Molnar.

At the end of my deanship, during a reorganization of the college, the laboratory was moved to the University of Colorado at Boulder. Under the superb leadership of Kevin Welner it morphed into The National Education Policy Center (NEPC). NEPC has become a leader in debunking the numerous silly and even dangerous policies that arise from the many so-called "think tanks" in our nation. Too often these "think tanks" are no more than propaganda mills for conservative individuals and for other anti-public school advocates. I am a proud founding fellow of NEPC, and for the last few years I have had the honor of giving out

23 The 2015 Bunkum award ceremony can be seen here: http://nepc.colorado.edu/thinktank/bunkum-awards/2015 This site also allows access to previous years' Bunkum award ceremonies.

${ }^{24}$ Laczko-Kerr, I., \& Berliner, D.C. (2002. The effectiveness of "Teach for America" and other under-certified teachers on student academic achievement: A case of harmful public policy, Education Policy Analysis Arcbives, 10(37), http://dx.doi.org/10.14507/epaa.v10n37.2002 See also: Laczko-Kerr, I., \& Berliner, D. C. (2003). In harm's way: How under-certified teachers hurt their students. Educational the annual Bunkum award for the worst policy papers of the previous year. Our ceremony is a lot of fun, unless you are the recipient of one of our Bunkums! ${ }^{23}$

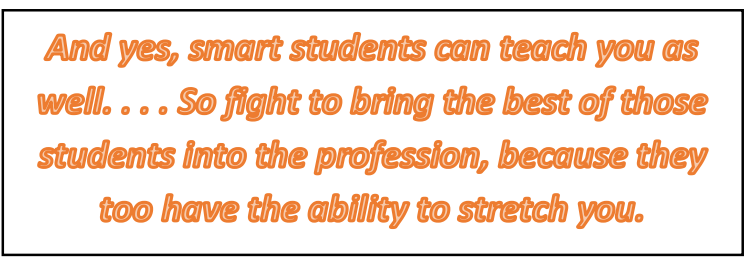

During this time period I also found the rationales supporting Teach for America (TFA) and other kinds of "alternatively trained" teachers not only unconvincing, but possibly dangerous for our democracy. The danger, I thought, was that poor children would be assigned those ill prepared teachers, while children in schools that serve the wealthy would never be allowed to be taught by such poorly prepared individuals. This proved to be an accurate prediction. I conducted some research in this area with my talented doctoral student Ildiko LaczkoKerr. We were able to demonstrate how under-certified teachers, such as those from TFA, harm students. ${ }^{24}$

Around this time I started work with another doctoral student who now is internationally known and also my esteemed colleague at ASU, Audrey AmreinBeardsley. I had started to worry about all the testing required under George Bush's No Child Left Behind Act (NCLB), and she and I worked on a number of papers that were among the first to attack the high stakes testing movement. ${ }^{25}$ It took a decade

Leadership, 60(8), 34-39. Retrieved February 1, 2004 at http://www.ascd.org/cms/objectlib/ascdframe set/index.cfm?publication=http: $/ /$ www.ascd.or $\mathrm{g} /$ authors/ed_lead/el200305_laczkokerr.html ${ }_{25}$ Amrein, A., \& Berliner, D. C. (2002). Highstakes testing, uncertainty, and student learning. Education Policy Analysis Archives, 10(18), http://dx.doi.org/10.14507/epaa.10.2002 See also: Amrein-Beardsley, A. \& Berliner, D. C. (2003,). Re-analysis of NAEP math and reading scores in states with and without high-stakes tests: Response to Rosenshine. Education Policy Analysis Archives, 11(25), 
and a half, but the subsequent federal law to replace NCLB, the Every Student Succeeds Act (signed December, 2015) recognizes that we were right-high stakes assessments have many more destructive than helpful qualities.

I wanted to continue this work and found funds to support a post-doctoral student, the remarkably able Sharon Nichols, who became my close friend and working colleague. We did a series of articles together, some with our colleague Gene Glass, assessing whether the social pressure to achieve higher test results in some states actually resulted in greater achievement than was true in states where there was little pressure to achieve well on tests. This was one of the key ideas behind the reliance on high stakes testing in NCLB. The theory of action behind NCLB was that pressure to perform well, along with public shaming if achievement test scores did not go up, would result in America's students performing better on tests of achievement. But in a clever study that we designed to test this hypothesis we found no evidence, whatsoever, that this approach actually worked. ${ }^{26}$

Sharon Nichols and I brought our ideas about the blatant stupidity of the NCLB bill together for a book, Collateral Damage: The effects of high-stakes testing on America's schools. ${ }^{27}$ In that book we

http://dx.doi.org/10.14507/epaa.v11n25.2003 See also Amrein, A., \& Berliner, D. C. (2003, February). The Effects of High-Stakes Testing on Student Motivation and Learning. Educational Leadership, 60(5), 32-38. Retrieved 2/1/ 2004 from:

http://www.ascd.org/cms/objectlib/ascdframe set/index.cfm?publication=http://www.ascd.or $\mathrm{g} /$ authors/ed_lead/el200302_amrein.html ${ }^{26}$ Nichols, S. L., Glass, G. V, \& Berliner, D. C. (2006). High-stakes testing and student achievement: Does accountability pressure increase student learning? Education Policy Analysis Archives, 14(1). Retrieved from: http://epaa.asu.edu/epaa/v14n1/ See also Nichols, S. N., \& Berliner, D. C. (2008). Testing the joy out of learning. Educational Leadership, 65(6), 14-18. See also Nichols, S. N., \& Berliner,

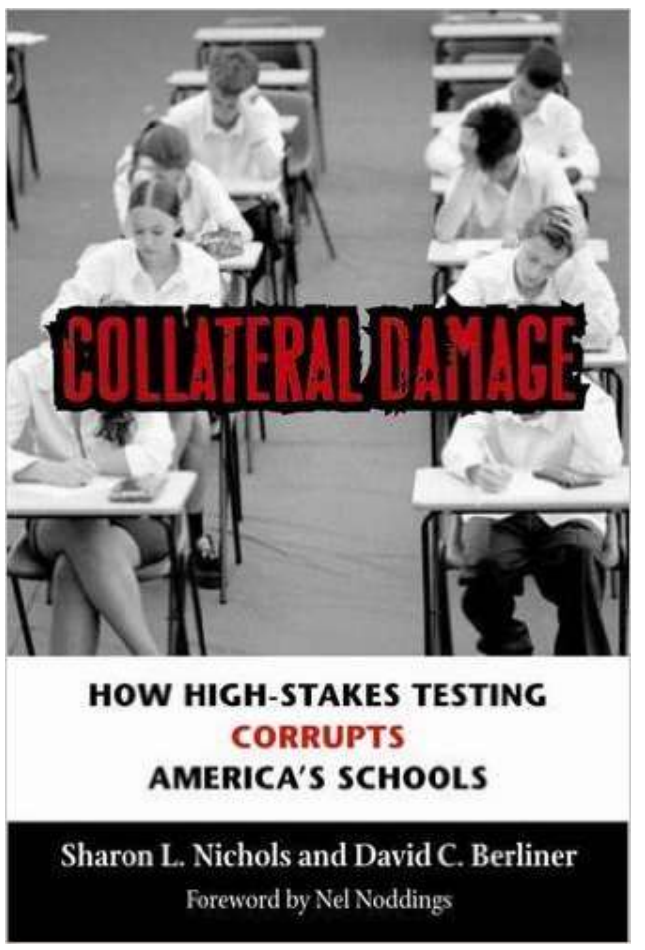

demonstrated the ubiquity of (Donald) Campbell's law. ${ }^{28}$ In 1975, he stated that when you over-value an indicator, say an achievement test score, then the indicator and the people who rely upon it, may both be corrupted. The cheating scandals that have plagued NCLB and other programs relying on achievement test scores as indicators of educational quality all demonstrate Campbell's law in action. With this powerful social science law as backing, Nichols and I predicted the harmful effects

D. C. (2008). Why has high-stakes testing so easily slipped into contemporary American life? Phi Delta Kappan, 89(9), 672-676. [Reprinted as Nichols, S. N., \& Berliner, D. C. (2008). Why has high-stakes testing so easily slipped into contemporary American life? Education Digest, 74(4), December, 2008, 41-47.]

${ }^{27}$ Nichols, S. N., \& Berliner, D. C. (2007). Collateral Damage: The effects of high-stakes testing on America's schools. Cambridge, MA: Harvard Education Press.

${ }^{28}$ Campbell, D. T. (1975). Assessing the impact of planned social change. In G. Lyons (Ed.), Social research and public policies: The Dartmouth/OECD Conference. (pp. 3-45). Hanover, NH: Dartmouth College, The Public Affairs Center. 
of the NCLB bill and began working for its demise.

While working on the non-effects and the negative effects of our federal government's testing programs, and after co-authoring The Manufactured Crisis, I realized that so much of the perception that our nation was not achieving well was due to out-of-school influences. These out-ofschool factors affected school and individual student performance a lot more than did inschool factors. I decided that the cause of our nation's mediocre average scores on international tests (say, the Program for International Student Assessment, (PISA), or national tests (say ACT or SAT), was only rarely the fault of teachers, administrators, or the curriculum we were using. The problem America had was inequality in income, affecting housing, neighborhood life, and the social, intellectual, and fiscal capital of the cohort with whom one attends school. I turned my attention to these issues and have stayed with that theme more than any other for the last two decades. ${ }^{29}$

In 2016, as I write this, and in spite of all the push back by scholars and practicing educators, American education policy continues to be chaotic, politicized, and at times, anti-democratic. Many myths about education are promulgated by extremely wealthy individuals and by corporations, often through their legislative activities organized by the American Legislative Exchange Council (ALEC). The blatant lies and the many myths about education that we learn about every day were the impetus for the book Gene Glass and I coauthored. Gene's creativity, intellect, and skillful writing helped make our book a

29 An example of these concerns are found in Berliner, D. C. (2009). Poverty and potential. Out-ofschool factors and school success. Boulder, CO; Tempe, AZ: Education and the Public Interest Center, University of Colorado \& Education Policy Research Unit, Arizona State University. Retrieved March 10, 2009, from:

http://epicpolicy.org/publication/poverty-andpotential. See also Berliner, D. C. (2013). Effects of inequality and poverty vs. teachers and schooling on America's youth. Teachers College best seller in 2014-2015. We wrote Fifty Myths and Lies That Threaten America's Public Schools with over a dozen of our graduate students. ${ }^{30}$ To our delight, our book seems to have become a favorite with school board members and administrators throughout the US, exactly for whom the book was written.

\section{Lessons Learned From My Unexpectedly Successful Career}

1. Facts are good to have. If you enter the policy arena as a traditional educational researcher you soon learn that opinions are rock solid, while facts are negotiable. But you cannot give in to this tendency and maintain your integrity as a scholar. As N. L. Gage taught me, "stay close to facts." What I add to his admonition, is this: "If you have facts to support a position, it is perfectly appropriate to beat some people over the head with them." The Manufactured Crisis was a biting and snarky book, but the facts that Bruce Biddle and I presented were unassailable. Collateral Damage was hard hitting and pointed out the stupidity inherent in the NCLB bill, but the facts that Sharon Nichols and I presented remain unchallenged. Our 50 Myths book makes fun of people who have said ludicrous things, but the facts that Gene Glass and I present are, so far, uncontested. Aldous Huxley said facts do not cease to exist because they are ignored. The philosopher Denis Phillips said something like "Worry about Warrant should never Wane." Our obligation as scholars in the policy arena is to make assertions and craft policies that are well warranted.

Record, 115(12), Retrieved March 1, 2013, from http://www.tcrecord.org/content.asp?contentid $\equiv 16889$ And also Berliner, D. C. (2006). Our impoverished view of educational reform. Teachers College Record, 108(6), 949-995. Retrieved July 21, 2014, from http://www.tcrecord.org/content.asp?contentid $=12106$

30 Berliner, D. C., Glass, G. V, \& Associates. (2014). Fifty myths and lies that threaten America's public schools. New York: Teachers College Press. 


\section{Try to write often for the press} and popular magazines, not just for professional journals. We are focused on a field of practice that is paid for by public taxes, important for the preservation of our democracy, and an important part of both childrearing and communal life. Your wellwarranted opinions about education need to be a part of our public discourse. Facts may help us to determine if charter schools or private schools work as well as they claim to, and they generally do not. But thoughtful opinions about the role of charters and private schools, or the support of religious private schools with tax money, are not factual issues but philosophical issues. Education researchers sometimes have thought more deeply about these issues than the general public and should share their thinking.

For example, in the area of bilingual education we know that immersion programs for English Language Learners are not as successful as, say, dual language schooling. Shouldn't our scholars in this area be writing newspaper "op-eds," letters to the editor, magazine articles and opinion pieces on issues like these for the general public? Because we too often write for a small group of scholars in our field of expertise, and we gain tenure for that work, we sometimes forget something. We forget that teachers, administrators, school board members and taxpayers among the general public need help in understanding the enterprise of public education with the aid of our scholarship.

I was pleased when I served as dean to reward our faculty for precisely these kinds of activities, as well as for the more traditional scholarly activities. We did increase our public visibility as a college during the years I was dean, though sometimes acting as thorns in the side of the Arizona legislature. I once had to remind the governor of our state that they paid us to be professors. And so, not to profess-not to give our well-warranted opinions on education issues-would be an abrogation of our professional responsibility. This did not sit well with her.

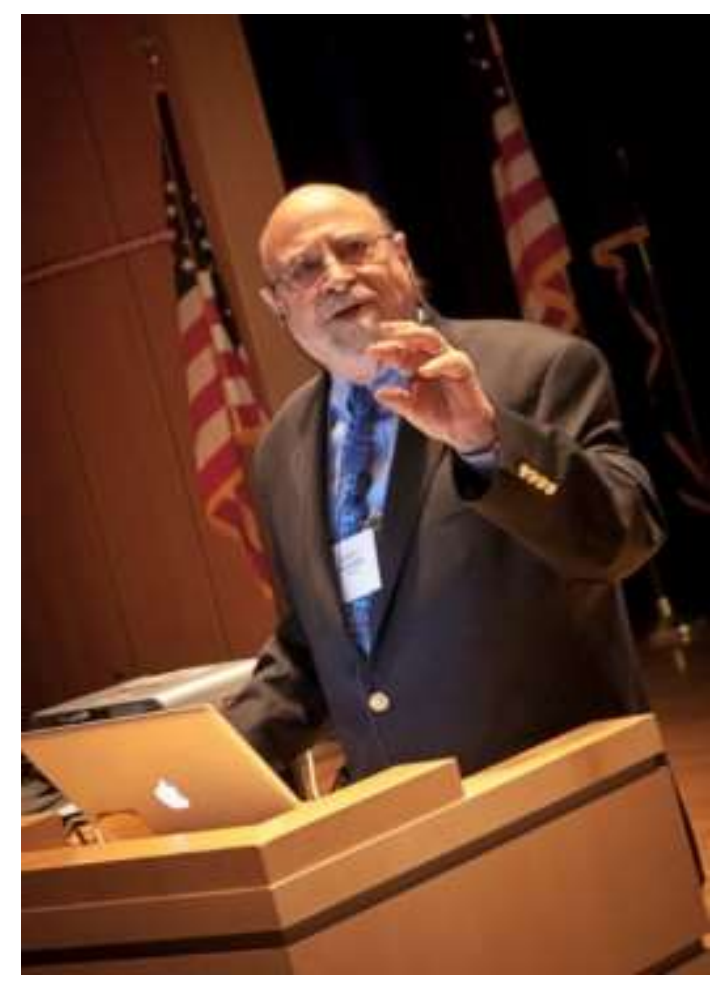

\section{Eschew the term "data}

driven." I am a fan of "data," of "facts" when we can pin them down, of probabilities and effect sizes as best we can estimate them. But I am readily incensed by those in policy who chant that we must be "data driven." So many of the policies derived from assessment data in education, and in particular the assessments of teachers through standardized achievement tests, strike me as an abdication of our responsibility as intelligent human beings. Data cannot stand on their own. Data come to us loaded with many caveats, and must be interpreted by knowledgeable and caring humans. Data driven decision-making is a ridiculous idea, though frequently espoused by politicians and some educators who know nothing about how education data sets can inform them.

On the other hand, data informed decision-making is sensible and should be supported. An example will suffice. If a teacher gets a poor "value added" score three years in a row, some district policies demand that such a teacher be fired. This is data driven decision-making. But did that teacher have a few more special education children in his class because he was 
particularly good with such students? Did that teacher have a few more English Language Learners than other teachers because she happened to be fluent in their home language? Did those teachers ever have professional development that would help teach the content that was on the tests used to assess their children? These and many other relevant questions need to be answered.

The point is that unless all these other influences on achievement can be accounted for statistically, and they cannot, then the "value added" metric for this teacher cannot be the basis of an important decision such as firing that teacher.

Achievement test data that may reliably and validly help us understand a student's acquisition of course work, are not likely to be valid for making inferences about teacher quality. Thus, such data should not be used for high-stakes decisions about teachers. Nevertheless, that same data could serve as the perfect reason to hold a conversation with a teacher about his or her performance and how it might be improved. Data informed conversations may be useful, while data driven decisions are frequently inappropriate.

4. Theory may be overrated. The journals and the scholarly community value "theory." But I have done a lot of research on teachers and teaching without much theory to guide me. We deal with the practical in education, and the practical is filled with complexity, some of which is hard to fit into psychological or any other social science theory.

Context is very important in educational research, and it is why I have such great respect for qualitative research. Qualitative research may be theory guided, or the data collected may be interpreted from a theoretical perspective, but that style of research is always committed to studying complexity by describing it well. The best

\footnotetext{
${ }^{31}$ Berliner, D. C. (1993). The science of psychology and the practice of schooling: The one hundred year journey of educational
}

scholars in the field seek thick description. Such research seeks to capture and make sense of the richness of events observed-a classroom, a lesson on the Constitution, a meeting with a parent, a school board session-with as little observer bias as possible. Some of the work I did on the study of teaching, such as teachers' use of time, or the development of teachers' expertise, or the uses of microteaching, and some of my policy work on assessment of teachers with standardized achievement tests, or on the excellence of America's schools, or on retention in grade, was almost atheoretical.

A good question is a good question, and should be pursued. Working from a Piagetian or Vygotskian theory is nice, and thinking about the world from a Freirean position, or asking what would Derrida say, is also to be lauded. But in my research career, a good question sensibly answered is worth its weight in gold. So I have come to believe that dust-bowl empiricism is too often dismissed as inadequate, and that theory in education research is too often over emphasized. I am more impressed with the quality of the question asked and the attempt to answer it, and less impressed with the quality of the theory from which it might have been derived.

\section{There is a strong need for William James's intermediate inventive mind. William James, a grandfather of educational psychology, understood the relationship of research and teaching. But E. L. Thorndike, the father of educational psychology did not. Thorndike told his graduate students not to spend time in schools, it would keep them from doing good research! ${ }^{31}$ Thus the laboratory/sanitized/controlled version of educational psychological research held sway for decades. But the reality of classrooms, their complexity and uniqueness, was too often ignored. Researchers acted as if school}

psychology from interest, to disdain, to respect for practice. Op Cit. 
personnel were ignorant not to use their latest findings on transfer, or advance organizers, or reinforcement and punishment, or the role of previous knowledge, or formative assessment, and the like. James's solution was to advocate for an intermediate inventive mind, someone with research skills and knowledge, who understands schools and classrooms and can help teachers incorporate ideas from the research community. We desperately need such people or our field of education research will continue to develop too many inert ideas.

Toward this end, at ASU we have tried, quite imperfectly, to build our EdD programs (not our PhD programs) around this idea. Along with the training of our next generation of researchers, we have tried to turn out educators well enough versed in traditional research to understand what we believe to be good for education, and translate that into forms of action research that might influence classrooms and schools in the real world. We seek to train "intermediate inventive minds" to bridge the gap between the research community and the classroom. Many schools confuse the goals of the PhD and the EdD degree. I think we have an obligation to keep these degrees separate but equal in their value to the broad profession of education which we serve. I hope we can do a better job in drawing these distinctions than we have in the past.

\section{Do not confuse the power of our education system with the power of the out-of-school factors that influence our students' lives. While I have devoted my professional life to the study of teaching, learning, and schooling, I have come to realize that James Coleman was correct}

32 Coleman, J. S., Campbell, E. Q., Hobson, C. J., McPartland, J., Mood, A. M., Weinfeld, F. D., ... York, R. L. (1966). Equality of educational opportunity. Washington, DC: U.S. Government Printing Office. See also this review of Coleman et al. (1966) on the 50th anniversary of its publication: Powers, J. M., Fischman, G. E., \& Berliner, D. C. (in press). Making the visible when writing 50 years ago. ${ }^{32}$ One's family, neighborhood, income, and school cohort influence the outcomes of schooling much more than do teachers and the schools that students attend. The data are clear: The variance accounted for by teachers on standardized achievement tests may be only about 10\%. Outside-of-school factors are more powerful determinants of a child's performance on these standardized achievement tests than are teachers. But that doesn't mean that teachers have no effects. They do.

Teachers daily affect the lives of their students, truly touching eternity, and they greatly influence the performance on the tests given in their own classrooms. But they do not affect their students' standardized achievement test scores very much. If teachers, education researchers, and politicians truly seek to have higher scoring students on standardized achievement tests (which so many citizens use to judge our schools), they need to be a lot more progressive and politically active. They need to insure that the influential outof-school factors in the lives of our students are those that affect the metric we most frequently use to judge our schools, the standardized achievement test, positively rather than negatively.

As Nelson Mandela said, "Overcoming poverty is not a task of charity, it is an act of justice. Like slavery and apartheid, poverty is not natural. It is man-made and it can be overcome and eradicated by the actions of human beings. " 33 Poverty in our country is a political issue. It must be solved by political action because with poverty comes more single parenthood, more births to teenagers, more food insecurity, more low birth-weight babies (and thus more children in need of

invisible: Willful ignorance and the nexus of poverty in educational research. Review of Research in Education, 2016: Education Research and Its Second Century.

${ }^{33}$ Retrieved March 8, 2016, from http://news.bbc.co.uk/2/hi/uk news/politics/ $\underline{4232603 . s t m}$ 
special education in low income school districts), more mental illness of parents, more illegal drug use, and many other things that afflict the poor. Big improvements in standardized achievement test scores will come about only by improvements in the living conditions of many American families. Standardized achievement test scores will not be improved much by the research community's efforts to improve teaching, curriculum, and learning.

Because of this, researchers and teachers alike need to be more politically active than they are now if they want to see something other than very modest gains in students' achievement test scores. It really does take a village to raise a child. I strongly believe that America's teachers and schools cannot be as successful as they could be, no matter what research validated tools we give them, unless our society becomes more concerned about the social and economic living conditions of the families and communities in which our children are raised. Politics, not better research, will achieve more to help our children do well in school.

\section{Hang out with smart people.}

In sports they often tell a novice to play with players who are better than they are, because they can learn so much more from them. A career in research works the same way. I am sure that a good deal of my productive scholarship was because I was lucky enough to hang out with smart teachers and friends, and I simply repeated to others a lot of what they said or ruminated about. I am vain enough to believe that I added value to what they taught me, but smart friends and teachers really do raise your game. Studying with Stanford professors like Lee J. Cronbach was my first inkling of this insight. He had one of the finest minds of his generation, and I was lucky enough to be his research assistant. What you gain from people like him (and from my many co-authors and friends such as N. L. Gage, Bruce J. Biddle, and Gene V Glass) is not "knowledge" per se- texts can give you knowledge and so can any ordinary instructor. But the best mentors suggest ways of thinking about the world, habits of mind, for structuring how you think about the problems, issues, methods, and research in your field. Habits of mind are far more important than is mere knowledge. And yes, smart students can teach you as well, as so many of mine did. So fight to bring the best of those students into the profession, because they too have the ability to stretch you.

\section{If you are social, as I am, write}

with others. I have often written with others for stimulation, for the chance to become closer as colleagues and friends, and for one other reason that every writer knows about: Procrastination. Almost all writers know how to put off actually sitting down and writing, even those who enjoy the process as much as I do. A million reasons can be found, and given to oneself and one's editors, for delays in finishing a manuscript.

But I found that if I write with a student or a colleague I feel guilty if I am not doing my part. Perhaps it is my Jewish heritage, but guilt motivates! Not upholding my end of the writing bargain made between my co-author and me is a strong motivator to actually get the work done. So if you find yourself to be one who doesn't write enough, find a colleague and do a book, a chapter, or an article with them. If you are as social as I am, it will be a lot more fun and increase your productivity as well.

\section{Change what you do every 10}

or so years. In retrospect I realize that I have changed the focus of my research every decade or so. Some of my age mates in the research community have done the same thing. It is healthy. You don't get stale or end up repeating yourself. Furthermore, I am convinced that the reason so many great discoveries in science and medicine are made by relatively young scholars is because they see a field of study with new eyes. So, when more seasoned scholars approach a new area of scholarship they too approach it with new eyes, a fresh viewpoint, and 
considerably more experience than a young scholar. I think that this gives a seasoned scholar a great advantage upon entering a new field of study. In retrospect I am glad I moved my focus from the study of teaching and teacher education to the study of teachers use of time, then to the study of teacher expertise, then to the study of outside the school factors that affect performance inside the schools, then to a critique of the high stakes testing accompanying No Child Left Behind, then to the insidious effects of poverty on schooling, and more recently to debunking the many myths that permeate education policy. I should also add how much fun it is to skewer the many myth makers, whose regretful (and unscrupulous) opinions underlie so much of contemporary education policy.

10. Join many boards. I served on many boards, and I both learned a lot and think I helped make my profession, and the world, a little better. For example, I served on the Board of Directors of WestEd for about a decade. Helping to direct the organization and respond to their initiatives was a chance to guide an influential organization that took its board recommendations seriously. WestEd derives its income from funded proposals, so serving on the board always informed me of the "hot topics" for states and the federal government. It also gave me access to findings and reports before they were released. Furthermore, others on the board were terrific educators with a wide variety of skills and beliefs. I already stated my belief that hanging out with smart people makes you smarter. Boards are a perfect way to do that. You get to hang out with smart people who are committed to the same things you are committed to, but perhaps holding different ideas about how to accomplish the same goals.

For about six years I served also on the Educational Testing Service Research

\footnotetext{
34 Berliner, D. C. (1997). Educational psychology meets the Christian right: differing
}

Advisory Board. Some of the finest scholars in the country, both from inside ETS and from the larger research community, also served on that board. I hope I helped them, but I know that they helped me learn a lot about the work they were doing and why they chose to do that work, as well as the emerging trends in psychometrics, testing, and the technology involved in testing.

In some ways my most satisfying board work was the decade I spent advising Americans United for Separation of Church and State. I have long held an interest in religious intrusions into our public schools. ${ }^{34}$ This board provided me a chance to work with patriots-people who were devout Christians and Jews as well as atheists-but who all understood why we need to fight to keep our schools secular. Our job was to defend the first amendment, and in doing so, schooling become a big part of the litigation agenda for Americans United. I learned a lot and was proud of my role in defending the constitution. Again, being with smart and committed professionals taught me a lot.

I mention these three but I served also on the board of a little consulting company, NOMOS, on various boards and councils of AERA and APA, and I still serve on the editorial boards of some journals, particularly Teachers College Record and Educational Policy Analysis Archives. In each case I think I contributed to the welfare and growth of the organizations I served, but at the same time they each contributed to my understanding of the world and my profession, and my service gave me a broader friendship group that has enhanced my life. It doesn't take a lot of time-a few days a year to engage in these learning and helping activities. And you might get a good meal out of the organization, but don't expect pay or stock options. In case you have not noticed, educational organizations are not like industrial organizations! On the other hand, you'll have enriched communal life and you will grow smarter yourself?

views of children, schooling, teaching, and learning. Teachers College Record, 98, 381-416. 


\section{Conclusion}

My biggest failure now, at the end of my career, is that I have made few inroads in changing the beliefs of sizable numbers of politicians and others in positions of power, particularly those in media. So many of these people hold our schools and teachers responsible for outcomes that schools and teachers cannot easily influence. It seems very clear to me now that it is poverty, along with its correlates and sequelae, that most influence student and school success, at least when that success is measured by standardized achievement tests.

I think that the reform efforts of the last two decades have failed because they make use of rewards and punishments for schools and teachers based on the assessment of students with standardized achievement tests. This is occurring even though we know that children and schools do well or poorly on those tests as a function of such things as neighborhood, social class, family income, child-care availability, cohort, and the like. One of the most insightful writers about these issues, the late Jean Anyon, said it best: "Attempting to fix inner city schools without fixing the city in which they are embedded is like trying to clean the air on one side of a screen door." 35

It is this insight that I work with. It is this message I bring to whomever will listen among our nation's misguided voters and political leaders. I haven't given up my interests in research on teaching and teacher education at all. But I have chosen to fight some policy battles so that teachers and teacher education programs will not be blamed for the problems of a society that cares too little about those in poverty and the schools that children from those neighborhoods attend. Fighting for

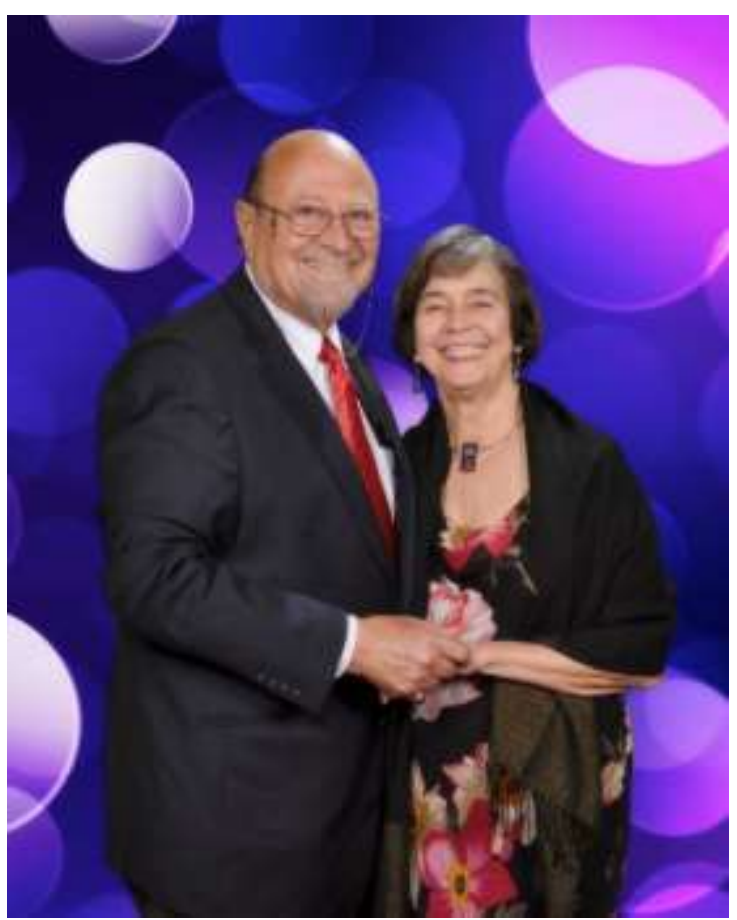

David Berliner and Ursula Casanova

recognition of these facts about schooling keeps me younger and angrier than I might otherwise be in my old age.

I certainly have had some luck, and very supportive friends and colleagues to go along with my hard work, as I tried to make a contribution to each of the different fields that captured my interest. This work was supported over the last three decades by my wife, the very insightful educator Ursula Casanova, who has contributed in so many ways to both my writing and to the quality of the life that I lead. I thank her profoundly for that, and for the three children she brought into my life, as well: Lisa, Carlos, and Leticia. I hope that the lessons I have learned are helpful to the next generation of scholars in education research and policy. That was what Sig Tobias had as his goal as he planned for this series, and Dexter Fletcher and I agreed to help.

35 Anyon, J. (1997). Ghetto schooling: A political economy of urban school reform. New York: Teachers College Press. 


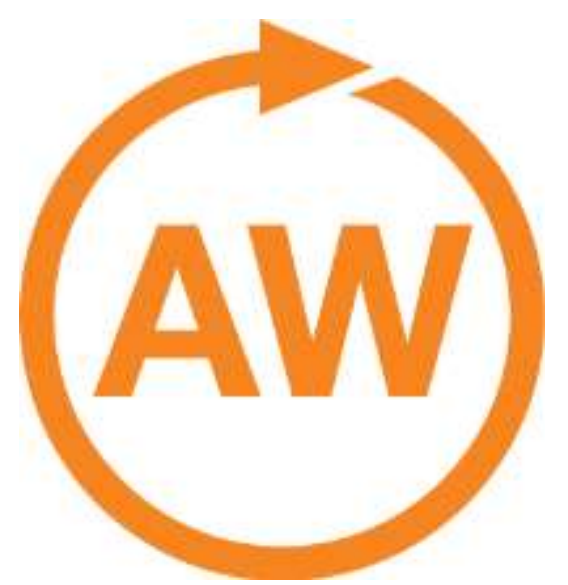

About Acquired Wisdom

This collection began with an invitation to one of the editors, Sigmund Tobias, from Norman Shapiro a former colleague at the City College of New York (CCNY). Shapiro invited retired CCNY faculty members to prepare manuscripts describing what they learned during their College careers that could be of value to new appointees and former colleagues. It seemed to us that a project describing the experiences of internationally known and distinguished researchers in Educational Psychology and Educational Research would be of benefit to many colleagues, especially younger ones entering those disciplines. We decided to include senior scholars in the fields of adult learning and training because, although often neglected by educational researchers, their work is quite relevant to our fields and graduate students could find productive and gainful positions in that area.
Junior faculty and grad students in Educational Psychology, Educational Research, and related disciplines, could learn much from the experiences of senior researchers. Doctoral students are exposed to courses or seminars about history of the discipline as well as the field's overarching purposes and its important contributors. .

A second audience for this project include the practitioners and researchers in disciplines represented by the chapter authors. This audience could learn from the experiences of eminent researchers-how their experiences shaped their work, and what they see as their major contributionsand readers might relate their own work to that of the scholars. Invitations to potential authors were accompanied by Tobias' chapter in this series for illustrative purposes. Authors were advised that they were free to organize their chapters as they saw fit, provided that their manuscripts contained these elements: 1) their perceived major contributions to the discipline, 2) major lessons learned during their careers, 3 ) their opinions about the personal and 4) situational factors (institutions and other affiliations, colleagues, advisors, and advisees) that stimulated their significant work.

We hope that the contributions of distinguished researchers receive the wide readership they deserve and serves as a resource to the future practitioners and researchers in these fields. 


\title{
education review // reseñas educativas a multi-lingual journal of book reviews \\ editors: gustavo e. fischman / melissa cast-brede / gene v glass
}

Supported by the Mary Lou Fulton Teachers College, Arizona State University

Acquired Wisdom is

Edited by

Sigmund Tobias

University at Albany

State University of New York
J. D. Fletcher

Institute for Defense Analyses

Alexandria VA
David C. Berliner

Arizona State University

Tempe AZ

\author{
Advisory Board Members \\ Gustavo Fischman, Arizona State University \\ Arthur C. Graesser III, Memphis State University \\ Teresa 1. McCarty, University of California Los Angeles \\ Kevin Welner, Colorado State University
}

\begin{abstract}
Education Review/Reseñas Educativas/Resenhas Educativas is supported by the edXchange initiative's Scholarly Communications Group at the Mary Lou Fulton Teachers College, Arizona State University. Copyright is retained by the first or sole author, who grants right of first publication to the Education Review. Readers are free to copy, display, and distribute this article, as long as the work is attributed to the author(s) and Education Review, it is distributed for non-commercial purposes only, and no alteration or transformation is made in the work. More details of this Creative Commons license are available at http://creativecommons.org/licenses/by-nc-sa/3.0/. All other uses must be approved by the author(s) or Education Review. Education Review is published by the Scholarly Communications Group of the Mary Lou Fulton Teachers College, Arizona State University.

Please contribute reviews at http://www.edrev.info/contribute.html.

Connect with Education Review on Facebook (https://www.facebook.com/pages/EducationReview/178358222192644) and on Twitter@EducReview
\end{abstract}

